\title{
Community Opinions on Wildlife, Resource Use and Livelihood Competition in Kimana Group Ranch Near Amboseli, Kenya
}

\author{
Moses Makonjio Okello*, ${ }^{*}$ Eric Buthmann ${ }^{1}$, Benjamin Mapinu ${ }^{2}$ and Henry C. Kahi ${ }^{2}$ \\ ${ }^{I}$ The School for Field Studies, Center for Wildlife Management Studies, P.O. Box 27743 - 00506, Nairobi, Kenya \\ ${ }^{2}$ Department of Animal Physiology, University of Nairobi, P. O. Box 30197, Nairobi, Kenya
}

\begin{abstract}
Kimana Group Ranch (KGR) is a critical wildlife dispersal area for Amboseli National Park in Kenya. But irrigated agriculture in the group ranch is leading to increased conflicts and competition for land and other critical resources. This study used semi - structured interviews with group ranch members on their interactions with wildlife, resource use and access, land use changes and livelihoods. Most group ranch members practiced agriculture as opposed to pastoralism. The community noted that critical resources such as water, pasture, plant resources and space were declining, and mostly available further from their homes. Members identified agriculture expansion and human development as the main land use changes. Most members also supported agriculture expansion as well as group ranch subdivision. Even most members supported wildlife use of their land, they were unhappy about the lack of compensation for losses. Most members wanted communal wildlife sanctuaries managed by the local community rather than a foreign investor. The competition for land and its resources due to increasing human population and land use changes is limiting wildlife use of the group ranch, and hence insularizing Amboseli Park. Potential solution is to have a negotiated land use plan that harmonizing environmental conservation and local livelihoods, while diversifying people's socio-economic opportunities to reduce poverty and dependence on natural resources.
\end{abstract}

Keywords: Community conservation, human-wildlife interactions, irrigated agriculture, land uses, wildlife dispersal.

Kenya is world renowned for its biodiversity and large wild mammal populations. However, increase in human population is rapidly leading to insularization of most of her protected areas [1]. This insularization can lead to species extinctions [2,3] and hence reduce progress in biodiversity conservation [4-7]. Common factors leading to insularization of protected areas are expansion of human activities and structures [8], tourism activities inside protected areas [9], and degradation of wildlife dispersal areas [10]. To avoid this, wildlife dispersal areas and migration corridors need to be maintained and kept open to allow wildlife to expand feeding and breeding grounds, other populations to supplant resident populations, encourage genetic diversity, and allow locally extinct species to restock former ranging areas, and hence reduce potential genetic drift and local extinctions [5, 11].

Communal group ranch subdivision into individual plots in Maasailand of Kenya [12-14] is another threat to Amboseli Park wildlife dispersal areas. The failure of the group ranch model of communal land ownership $[12,15]$ has led to concerted demand for individual land ownership, hence the glamour group ranch subdivision. Such demands have been increasing with time [16-18] with the majority support for individual ownership coming from the cultivators, the youth and landless, who hope to secure a piece of land for private use, ownership security and

*Address correspondence to this author at the School for Field Studies, Center for Wildlife Management Studies, P.O. Box 27743 - 00506, Nairobi, Kenya; Tel: +254722598884; E-mails: mokello@ fieldstudies.org, moses_okello@yahoo.com cultivation [14]. Despite widespread concerns that group ranch subdivision may fragment wildlife dispersal areas further, and interfere with their ranging $[19,20]$, individual ownership has been adopted in all group ranches in Amboseli area [14, 21, 22]. An emerging social consequence of subdivision is landlessness among the Maasai who sell newly acquired land to meet urgent and short-term financial needs $[19,23]$.

Agriculture is the main motive for the glamour for group ranch subdivision into individual as opposed to communal land ownership among the Maasai of Amboseli area. Agriculture consumes about $400 \%$ more water in rangelands than humans and animals combined [24], causing intense competition for this resource [20]. This is a major problem in semi-arid rangelands where often water is a major limiting resource for plant productivity and wildlife distribution [25]. When wildlife lives in close proximity to people, the impacts on their safety and livelihoods becomes a serious concern. Wildlife kill livestock and people, destroy crops, interfere with children walking to/attending school, and disrupt pastoralists tending herds [26]. These and other humanwildlife conflicts increase during the wet season when food and water become abundant in dispersal areas [27] making wildlife move away from dry season concentration areas into group ranch dispersal areas [18, 28].

It is important to establish the opinions of communities on challenges related to resources competition, land use and socio - economic challenges that will affect their livelihoods and environmental conservation. Kimana Group Ranch was the first among communities in Kenya to set up a wildlife conservation area in 1996 [29]. It was also among the first 
group ranches in Amboseli area to have active irrigated agricultural scheme [20]. Ten years after the establishment of Kimana Community Wildlife Sanctuary, it was important to establish if this initiative still has community support, if it significantly contributed to improved local livelihoods, improved tolerance for wildlife and got accepted as a as profitable land use option for the community. This study sought to establish current resource use, competition and interactions among people, wildlife and livestock, and discuss implications and consequences for these interactions and dynamics.

The specific objectives were to:

i) Establish local opinions and views concerning land and other resource use competition and implications of this on wildlife dispersal and local livelihood

ii) Establish opinions concerning Kimana Community Wildlife Sanctuary (KCWS) and electric fences, and how they have contributed to their local well-being

iii) Identify other critical resources and establish access to them by the local community

iv) Make appropriate recommendations on the way forward

\section{THE STUDY AREA}

The Amboseli ecosystem (which comprises Amboseli National Park, surrounding group ranches, and community wildlife sanctuaries) is a tourist destination [30] and essential wildlife ranging area [28] found in Southern Kenya. This wildlife rich area is located in Maasai country bordering Tanzania around the Mt. Kilimanjaro area. Protected areas in the area are not large enough to support most wildlife without accompanying dispersal areas [1, 28]. Kimana Group Ranch (KGR), a key Maasai communal land dispersal area for the protected area in the wet season, has a community-based wildlife sanctuary, Kimana Community Wildlife Sanctuary (KCWS) that also serves as an important dry season wildlife concentration area [29] for Amboseli. The group ranch is relatively small, with an area of $251 \mathrm{~km}^{2}$ (Fig. 1).

The area is semi-arid rangeland with a bimodal rainfall pattern [14]. The long rains occur from March to early June, and the short rains occur in October and November. The amount of rainfall received is influenced by Mt. Kilimanjaro which casts a rain shadow on the area. Moisture in the clouds is lost as rain when air masses move up the south side of Kilimanjaro and arrive on the north side of the mountain dry [31]. The area receives an annual rainfall of $210 \mathrm{~mm}$, with

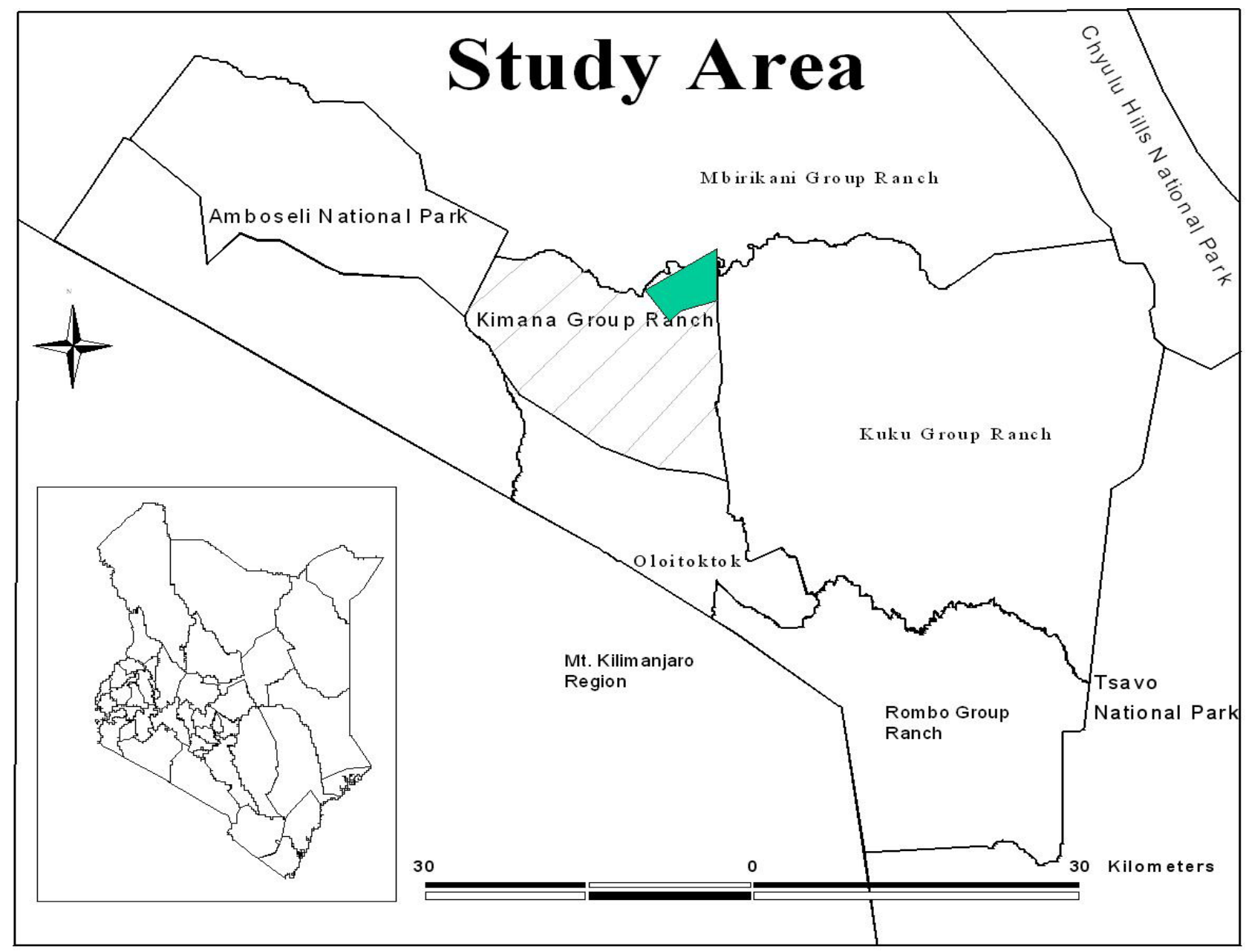

Fig. (1). The group ranches between Amboseli National Park and Tsavo / Chyulu Parks in southern Kenya. Shaded is the study area comprising of Kimana Group Ranch, with its community wildlife sanctuary (Kimana Community Wildlife Sanctuary, KCWS) shaded in solid shade. Inset is the map of Keny with region demarcations. 
$35 \%$ received during the short rains and $65 \%$ in the long rains [32]. These rainfall characteristics are typical of semiarid areas, also characterized by low and erratic rainfall and high temperatures.

The vegetation is dominated by grasses, shrubs, and Acacia species that are adapted to withstand periods of long drought. Kimana rangeland consists of variety of habitats, including dense and open shrub land, bush land, and woodland. The dominant vegetation in the riverine habitat is Acacia xanthophloea but Acacia tortillis and Acacia mellifera in drier areas [32]. Dominant perennial grass species such as Cenchrus ciliaris and Chloris roxburghiana are common in the area [33].

Soils in this region are volcanic, and generally highly saline and alkaline. The soils are also less well developed, hence shallow and generally unproductive, but can be very productive near water sources [31]. Agriculture practiced here is mainly irrigation [18, 34] except in areas near Kilimanjaro where rain fed agriculture is possible due to relatively higher rainfall of over $1,000 \mathrm{~mm}$ annually $[31,20]$.

Maasai group ranches in Tsavo - Amboseli ecosystem support and provide wildlife corridors and dispersal areas that link the protected areas in the ecosystem (Amboseli, Tsavo West and Chyulu Hills) and community conservation areas (such as Kimana Community Wildlife Sanctuary), allowing them to support large populations of seasonally migratory mammals [28]. The group ranches on their own also support populations of wild large mammals in an open landscape [17] with $70 \%$ of wildlife living outside the protected areas [26]. In support of wildlife conservation, KCWS was established in 1996 . KCWS is approximately 40 $\mathrm{km}^{2}$ in area and is located in the northeastern corner of KGR [29].

\section{METHODS}

Kimana Group Ranch land owners and land users (those who rent land for agricultural activities) throw interviews and group discussions. This was done by interviewing members using semi - structured questionnaires using a strata of land uses (farmer or pastoralism strata), clusters of human settlement (Maasai homestead) design units [18], across land use transect $[20,35]$.

The sampling unit for agricultural farms was a land use owner or lease of an agricultural land. This was necessary because the range of issues investigated concerned both land users and owners, particularly in fenced areas within Kimana Group Ranch [34] where group ranch subdivision was into individual ownership was done about thirty years ago. The sampling design therefore took into consideration the views of both cultivators (in irrigation schemes inside the electric fences) and the mainly pastoralist Maasai living in open range where they keep livestock. The Maasai lives in clusters of settlement in family (related or sometimes not related) settlements called bomas especially along rivers, roads and water points

To examine local community opinions, interviews were done using semi-structured questionnaires and discussions with key informants and stakeholders in Kimana Group Ranch. To obtain wider and representative information, cultivators in two electric fences (Namelok and Kimana) were considered a stratum of their own. Both Maasai and non-Maasai cultivators were interviewed within this stratum using a simple random sampling approach for farm plots (owners) [36, 37].

The second stratum was mostly Maasai pastoralists living in an open range (outside agriculture clusters confined in electric fences) where all homesteads were known. Due to their clustered settlements in bomas, a two stage sampling approach was used in which all clusters of settlements were located and included in sampling, and individual bomas were randomly selected in each cluster. Once bomas were selected, all households within each boma were included in the interview [36, 37]. At least a sampling effort of over $40 \%$ of the bomas was maintained in each cluster. The sampling unit for the pastoralism interviews was a household [38] within a boma.

The location and number of Maasai clusters and homestead settlements (bomas) outside the fences (bomas) and other settlement clusters were mapped in a previous preliminary study, and so it was possible to know the sampling effort and households from bomas (a boma comprises typically between one and five families) to be included in a random sample.

To ensure independence of the data collected, as well as getting representative wider views as possible, only an adult family head (man or woman) was interviewed from each household. The interview and discussion with each interviewee was done separately from anyone else. To further ensure robustness of tests, reliability of inference and conclusions, an effort was made to interview as many men and women (even though most Maasai women will not agree to give interviews when their husbands are present), while also ensuring a good sample size of households interviewed in each strata.

Interviews were done between July and September 2006. The local guides and interpreters were trained and used for exact translation into Maasai language from English. To ensure that the information asked was accurate, consistently phrased and presented in the same way from one interviewee to another, a discussion guided by a a semi - structured questionnaire with local interpreters was done question by question to ascertain the meaning, wording and expected responses from the interviewees. These "trained" local translators and interpreters (good in both Kiswahili and Maasai which are commonly spoken languages in the area) were retained throughout the study.

Before contacting the questionnaires interview, introduction of the interviewers and the general purpose of the interview were done. Questions focused on land use practices, resource use, forms of livelihoods, wildlife relationships, and group ranch communal management. After the interview, the interviewees were allowed to ask questions that they had for the researchers and make further comments about questions asked to enhance participatory discussions for further insights $[39,40]$. Later, results of the work was presented in a joint presentation in which local community members, group ranch officials and other stakeholders were invited for discussions and further clarification of issues.

All study issues raised in the questionnaire were tallied and synthesized on the Excel Spreadsheet for windows 
Table 1. Characteristics of Community Members Interviewee Opinions in Regards to land Use Changes and Human-Wildlife Interactions

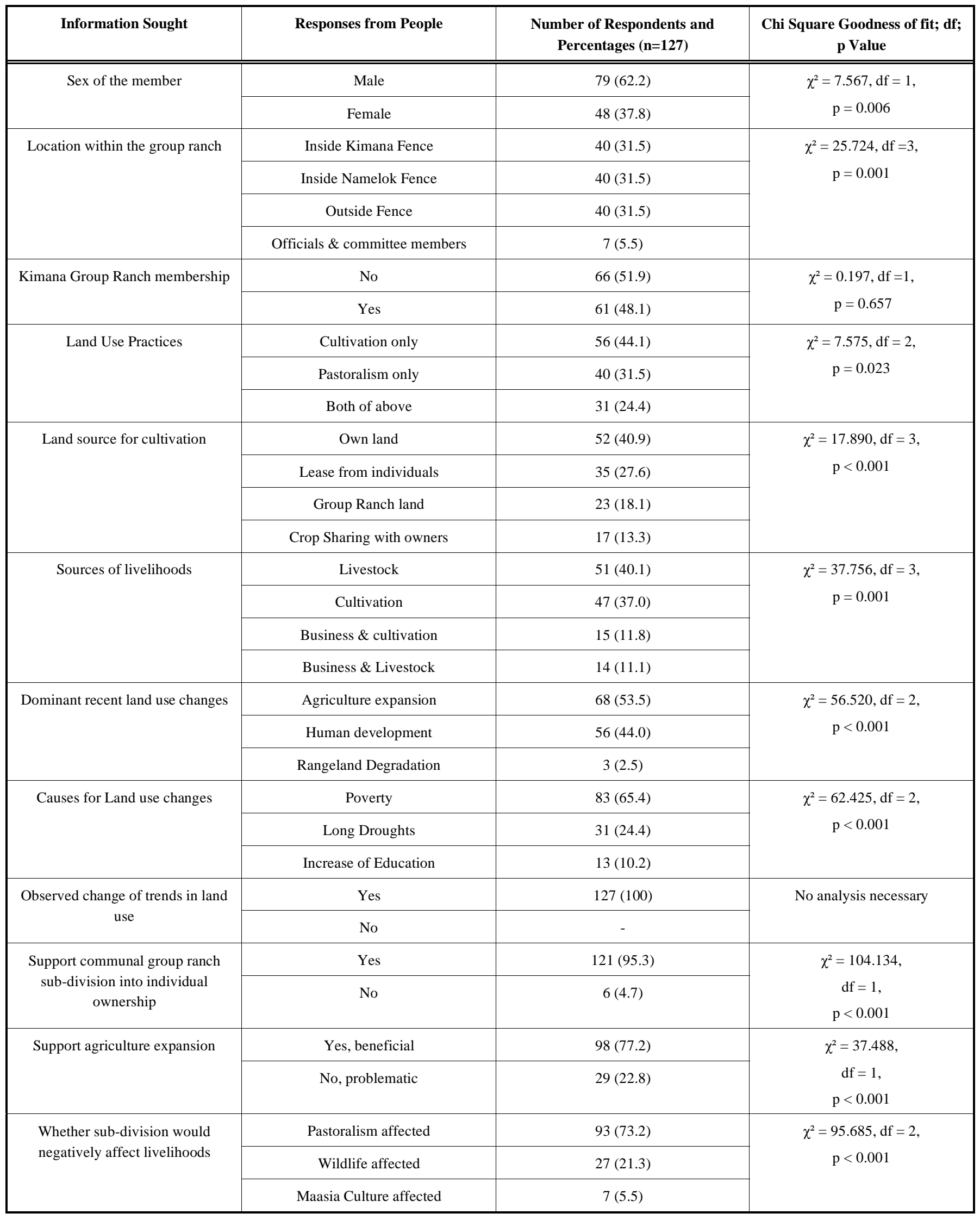


(Table 1). Contd....

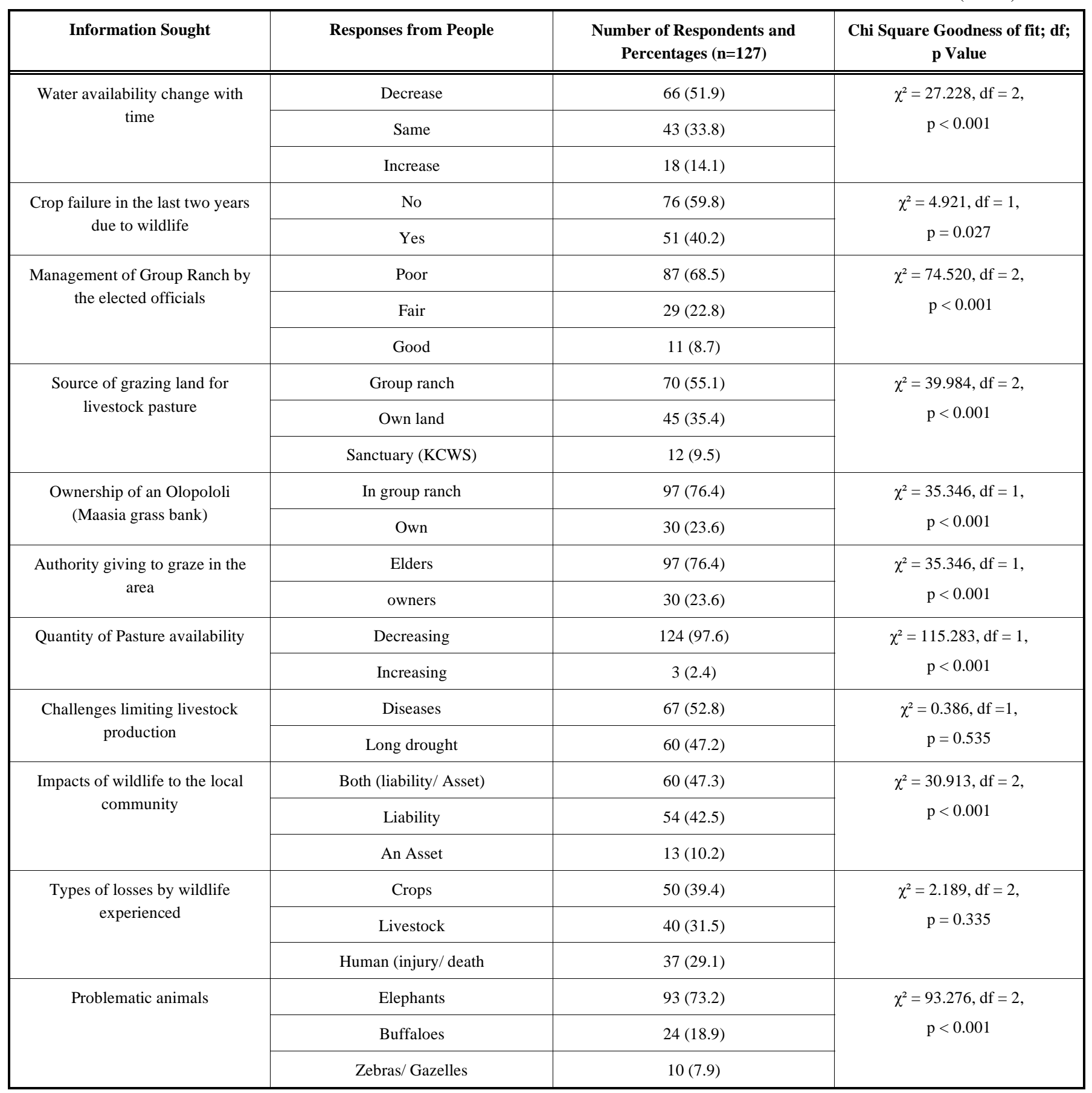

(Microsoft Corporation 1999). Frequencies of interviewed household heads giving a particular response were as well as differences in frequencies of particular responses of an issue were summarized and equality of frequencies tested using chi-square goodness of fit [38]. To establish factors influencing certain responses and particular relationships with specific attributes, a chi - square cross tabulations analysis was employed using SPSS Version 9.0 for Windows (SPPS Inc. 1998). Statistical tests were considered significant with $\mathrm{p}$ - values was equals to or less than 0.05 [38]. For goodness of fit, if the p-value was equal or less than 0.05 , then the frequencies were significantly different (and similar if $\mathrm{p}$-value was greater than 0.05). For Chi - square cross tabulations, if p-value was equal or less than 0.05 , then a response was dependent on an attribute, and independent of the attribute if $\mathrm{p}$ - value was greater than 0.05 .

\section{RESULTS}

All community members interviewed noted a significant changing trend in land use practices in the group ranch (Table 1). The majority of group ranch members practiced irrigation agriculture compared to those practicing pastoralism alone, while those practicing both land uses were a minority $(24 \%)$. Group ranch members who owned their own land for cultivation were more than those leasing from 
either other individuals or communal land. The majority (77\%) of the community members significantly supported agriculture expansion $\left(\chi^{2}=37.49, \mathrm{df}=1, \mathrm{p}<0.001\right)$ as the most beneficial form of land use in the area compared to other land uses in Kimana Group Ranch.

The main reasons given for a shift in land use to agriculture (Table 2) ranged from widespread poverty, long droughts and education induced changes culture respectively. Opinions on most popular land use type were independent of peoples sex, group ranch status or ethnicity, but dependent were dependent on location in the group ranch, age, level of education and group ranch membership. People living in electric fences favored agriculture as the main land use type, and were most ordinary group ranch members (unlike their group ranch officials) and mostly those with a lower level of education.
Communal land subdivision into individual ownership in Kimana Group Ranch (which is now complete), was supported by a significant majority of community members (Table 1). However, a majority of the members also noted that subdivision could negatively affect pastoralism, compared to wildlife free - ranging and use of the ranch. Support for communal group ranch sub-division (Table 3) was independent of sex, group ranch status, ethnicity and level of education, but dependent on location in the group ranch (most inside fences supporting it), age (young ones supporting more) and group ranch membership (more members than officials supporting it).

Availability of important resources for livelihoods such as water and pasture availability were also varied (Table 1). A majority of the community members $(52 \%)$ noted a decline in water availability, pasture, and wetland areas. For water needs, a majority relied mainly on irrigation water for

Table 2. Community Opinions on Land Use Changes Causes and Reasons Given for Land Use Changes and other Attributes of Kimana Group Ranch Members

\begin{tabular}{|c|c|c|c|c|c|c|c|c|}
\hline \multirow{2}{*}{\multicolumn{2}{|c|}{ Attributes }} & \multicolumn{2}{|c|}{ Land Use Change Frequency ( $\%$ ) } & \multirow{2}{*}{$\begin{array}{l}\text { Chi Square } \\
\text { Cross } \\
\text { Tabulations }\end{array}$} & \multicolumn{3}{|c|}{$\begin{array}{c}\text { Reasons for Land Use Change } \\
\text { Frequency (\%) }\end{array}$} & \multirow[t]{2}{*}{ Chi Square } \\
\hline & & Agriculture & Development & & Drought & Poverty & $\begin{array}{c}\text { Education } \\
\text { Increase }\end{array}$ & \\
\hline \multirow[t]{2}{*}{ Sex } & Male & $53(67.1)$ & $26(32.9)$ & \multirow{2}{*}{$\begin{array}{c}\chi^{2}=1.45^{\mathrm{a}} \\
\mathrm{df}=1 \\
\mathrm{p}=0.23\end{array}$} & $26(32.9)$ & $34(43.0)$ & $19(24.1)$ & \multirow{2}{*}{$\begin{array}{c}\chi^{2}=3.07^{\mathrm{a}} \\
\mathrm{df}=2 \\
\mathrm{p}=0.216\end{array}$} \\
\hline & Female & $37(77.1)$ & $11(22.9)$ & & $13(27.1)$ & $28(58.3)$ & $7(14.6)$ & \\
\hline \multirow[t]{2}{*}{ Location } & Inside Fence & $81(93.1)$ & $6(6.9)$ & \multirow{2}{*}{$\begin{array}{c}\chi^{2}=10.03^{b} \\
d f=1 \\
p=0.002\end{array}$} & $24(30.4)$ & $40(50.6)$ & $15(19.0)$ & \multirow{2}{*}{$\begin{array}{c}\chi^{2}=26.421^{b} \\
\mathrm{df}=2 \\
\mathrm{p}<0.001\end{array}$} \\
\hline & Outside Fence & $29(72.5)$ & $11(27.5)$ & & $32(80.0)$ & $5(12.5)$ & $3(7.5)$ & \\
\hline \multirow{3}{*}{$\begin{array}{c}\text { Group Ranch } \\
\text { status }\end{array}$} & Official & $3(42.9)$ & $4(57.1)$ & \multirow{3}{*}{$\begin{array}{c}\chi^{2}=1.81^{\mathrm{a}} \\
\mathrm{df}=2 \\
\mathrm{p}=0.41\end{array}$} & $2(28.6)$ & $1(14.3)$ & $4(57.1)$ & \multirow{3}{*}{$\begin{array}{c}\chi^{2}=19.81^{b} \\
\mathrm{df}=4 \\
\mathrm{p}=0.001\end{array}$} \\
\hline & Member & $37(68.5)$ & $17(31.5)$ & & $23(42.6)$ & $20(37.0)$ & $11(20.4)$ & \\
\hline & Non-member & $43(65.2)$ & $23(34.8)$ & & $38(62.3)$ & $21(34.4)$ & $2(3.3)$ & \\
\hline \multirow[t]{3}{*}{ Age } & $16-30$ & $25(43.9)$ & $32(56.1)$ & \multirow{3}{*}{$\begin{array}{c}\chi^{2}=6.190^{b} \\
d f=2 \\
p=0.05\end{array}$} & $15(26.3)$ & $17(29.8)$ & $25(43.9)$ & \multirow{3}{*}{$\begin{array}{c}\chi^{2}=15.57^{b} \\
\mathrm{df}=4 \\
\mathrm{p}=0.004\end{array}$} \\
\hline & $30-60$ & $41(65.1)$ & $22(34.9)$ & & $24(38.1)$ & $31(49.2)$ & $8(12.7)$ & \\
\hline & $>60$ & $5(71.4)$ & $2(28.6)$ & & $3(42.9)$ & $3(42.9)$ & $1(14.3)$ & \\
\hline \multirow[t]{3}{*}{ Tribes } & Maasai & $56(60.1)$ & $36(39.1)$ & \multirow{3}{*}{$\begin{array}{c}\chi^{2}=3.352^{\mathrm{a}} \\
\mathrm{df}=2 \\
\mathrm{p}=0.19\end{array}$} & $48(52.2)$ & $31(33.7)$ & $13(14.1)$ & \multirow{3}{*}{$\begin{array}{c}\chi^{2}=20.78^{b} \\
\mathrm{df}=4 \\
\mathrm{p}=0.001\end{array}$} \\
\hline & Other tribes & $15(45.5)$ & $18(54.5)$ & & $8(24.2)$ & $9(27.3)$ & $16(48.5)$ & \\
\hline & Non Citizens & $5(41.7)$ & $7(58.3)$ & & $3(25.0)$ & $7(58.3)$ & $2(16.7)$ & \\
\hline \multirow{4}{*}{$\begin{array}{l}\text { Education } \\
\text { Level }\end{array}$} & None & $52(75.4)$ & $17(24.6)$ & \multirow{4}{*}{$\begin{array}{c}\chi^{2}=17.25^{b} \\
\mathrm{df}=3 \\
\mathrm{p}=0.001\end{array}$} & $12(17.4)$ & $41(59.4)$ & $16(23.2)$ & \multirow{4}{*}{$\begin{array}{c}\chi^{2}=14.18^{b} \\
\mathrm{df}=6 \\
\mathrm{p}=0.028\end{array}$} \\
\hline & Primary & $17(68.0)$ & $8(32.0)$ & & $6(24.0)$ & $10(40.0)$ & $9(36.0)$ & \\
\hline & Secondary & $8(33.3)$ & $16(66.7)$ & & $7(29.2)$ & $6(25.0)$ & $11(45.8)$ & \\
\hline & Tartiary & $3(33.3)$ & $6(66.7)$ & & $3(33.3)$ & $1(11.1)$ & $5(55.6)$ & \\
\hline \multirow{4}{*}{$\begin{array}{l}\text { Group Ranch } \\
\text { Membership }\end{array}$} & Kimana & $53(86.9)$ & $8(13.1)$ & \multirow{4}{*}{$\begin{array}{c}\chi^{2}=30.77^{b} \\
\text { df }=3 \\
p<0.001\end{array}$} & $33(54.1)$ & $7(11.5)$ & $21(34.4)$ & \multirow{4}{*}{$\begin{array}{c}\chi^{2}=13.03^{b} \\
\mathrm{df}=6 \\
\mathrm{p}=0.043\end{array}$} \\
\hline & Mbirikani & $5(62.5)$ & $3(37.5)$ & & $2(25.0)$ & $4(50.0)$ & $2(25.0)$ & \\
\hline & Olgnlului & $4(25.0)$ & $12(75.0)$ & & $6(37.5)$ & $5(31.3)$ & $5(31.3)$ & \\
\hline & Others & $19(45.2)$ & $23(54.8)$ & & $15(35.7)$ & $16(38.1)$ & $11(26.2)$ & \\
\hline
\end{tabular}

${ }^{a}$ Land use changes were independent of sex, group ranch status and tribe. ${ }^{b}$ Land use change were dependent on location age, education land group ranch membership. 
Table 3. Relationship Between Opinions on Key Land Use, Livelihood, Wildlife Interactions and Interviewee Attributes of Kimana Group Ranch Members.

\begin{tabular}{|c|c|c|c|c|c|}
\hline $\begin{array}{l}\text { Interviewee } \\
\text { Attributes }\end{array}$ & $\begin{array}{c}\text { Support for Group } \\
\text { Ranch Subdivision } \\
\text { was Independent of } \\
\text { Attribute }\end{array}$ & $\begin{array}{c}\text { Opinion on Wildlife } \\
\text { as a Liability or Asset } \\
\text { was Independent of } \\
\text { Attribute }\end{array}$ & $\begin{array}{c}\text { Views on Types of } \\
\text { Wildlife Damages } \\
\text { was Independent of } \\
\text { Attribute }\end{array}$ & $\begin{array}{l}\text { Support for Free } \\
\text { Wildlife Ranging in } \\
\text { Group Ranch was } \\
\text { Independent of } \\
\text { Attribute }\end{array}$ & $\begin{array}{c}\text { Local People's } \\
\text { Source of Income } \\
\text { was Independent of } \\
\text { Attribute }\end{array}$ \\
\hline Sex & $\begin{array}{c}\chi^{2}=2.23^{b} \\
\text { df }=1 \\
p=0.135\end{array}$ & $\begin{array}{c}\chi^{2}=0.04 \\
\text { df }=1 \\
p=0.844\end{array}$ & $\begin{array}{c}\chi^{2}=0.428 \\
\text { df }=1 \\
p=0.513\end{array}$ & $\begin{array}{c}\chi^{2}=11.78^{a} \\
\text { df }=1 \\
p=0.001\end{array}$ & $\begin{array}{c}\chi^{2}=6.18 \\
\text { df }=3 \\
p=0.103\end{array}$ \\
\hline $\begin{array}{l}\text { Location in relation to } \\
\text { electric fence }\end{array}$ & $\begin{array}{c}\chi^{2}=7.84 \\
\text { df }=1 \\
p=0.005\end{array}$ & $\begin{array}{c}\chi^{2}=1.22 \\
\text { df }=1 \\
p=0.270\end{array}$ & $\begin{array}{c}\chi^{2}=7.216 \\
\text { df }=1 \\
p=0.007\end{array}$ & $\begin{array}{c}\chi^{2}=0.15 \\
d f=1 \\
p=0.701\end{array}$ & $\begin{array}{c}\chi^{2}=5.16 \\
\mathrm{df}=3 \\
p=0.160\end{array}$ \\
\hline Group Ranch status & $\begin{array}{c}\chi^{2}=0.44 \\
\text { df }=2 \\
p=0.805\end{array}$ & $\begin{array}{c}\chi^{2}=8.29 \\
d f=2 \\
p=0.016\end{array}$ & $\begin{array}{c}\chi^{2}=0.630 \\
\text { df }=2 \\
p=0.730\end{array}$ & $\begin{array}{c}\chi^{2}=29.85 \\
\text { df }=2 \\
p<0.001\end{array}$ & $\begin{array}{c}\chi^{2}=13.86 \\
\text { df }=6 \\
p=0.031\end{array}$ \\
\hline Age & $\begin{array}{c}\chi^{2}=73.99 \\
\text { df }=2 \\
p<0.001\end{array}$ & $\begin{array}{c}\chi^{2}=12.30 \\
\text { df }=2 \\
p=0.002\end{array}$ & $\begin{array}{c}\chi^{2}=3.838^{a} \\
\text { df }=2 \\
p=0.147\end{array}$ & $\begin{array}{c}\chi^{2}=7.11 \\
\mathrm{df}=2 \\
\mathrm{p}=0.029\end{array}$ & $\begin{array}{c}\chi^{2}=21.33 \\
d f=6 \\
p=0.002\end{array}$ \\
\hline Tribes & $\begin{array}{c}\chi^{2}=2.40 \\
\text { df }=2 \\
p=0.302\end{array}$ & $\begin{array}{c}\chi^{2}=8.42 \\
\mathrm{df}=2 \\
\mathrm{p}=0.015\end{array}$ & $\begin{array}{c}\chi^{2}=3.754 \\
\text { df }=2 \\
p=0.153\end{array}$ & $\begin{array}{c}\chi^{2}=6.98 \\
\mathrm{df}=2 \\
\mathrm{p}=0.031\end{array}$ & $\begin{array}{c}\chi^{2}=62.35 \\
\mathrm{df}=6 \\
\mathrm{p}<0.001\end{array}$ \\
\hline Education Level & $\begin{array}{c}\chi^{2}=5.29 \\
\mathrm{df}=3 \\
\mathrm{p}=0.152\end{array}$ & $\begin{array}{c}\chi^{2}=13.95 \\
\mathrm{df}=3 \\
\mathrm{p}=0.003\end{array}$ & $\begin{array}{c}\chi^{2}=1.836 \\
\mathrm{df}=3 \\
\mathrm{p}=0.607\end{array}$ & $\begin{array}{c}\chi^{2}=19.39 \\
\text { df }=3 \\
p<0.001\end{array}$ & $\begin{array}{c}\chi^{2}=64.24 \\
\mathrm{df}=9 \\
\mathrm{p}<0.001\end{array}$ \\
\hline $\begin{array}{l}\text { Group Ranch } \\
\text { Membership }\end{array}$ & $\begin{array}{c}\chi^{2}=27.03 \\
\mathrm{df}=3 \\
\mathrm{p}<0.001\end{array}$ & $\begin{array}{c}\chi^{2}=3.56 \\
\mathrm{df}=3 \\
p=0.314\end{array}$ & $\begin{array}{c}\chi^{2}=3.323 \\
\mathrm{df}=3 \\
\mathrm{p}=0.344\end{array}$ & $\begin{array}{c}\chi^{2}=41.36 \\
\mathrm{df}=3 \\
\mathrm{p}<0.001\end{array}$ & $\begin{array}{c}\chi^{2}=38.98 \\
\mathrm{df}=9 \\
\mathrm{p}<0.001\end{array}$ \\
\hline
\end{tabular}

${ }^{a}$ All chi - square values with a p - value less than or equals to 0.05 are significant. So the null hypothesis should be rejected, and should show that the responses are dependent on the attributes.

${ }^{\mathrm{b}}$ All chi - square values with a $\mathrm{p}$ - value greater than 0.05 are not significant. So we fail to reject the null hypothesis, and should show that the responses are independent on the attributes.

cultivation (Table 1). While a majority of the members were still relying on open communal range for grazing, some were now investing in their own Olopololi (Maasai grass bank for livestock dry season grazing) to deal with the scarcity. Many members noted that wetlands were increasingly being converted or drained to create agricultural land and pasture.

Almost half of the group ranch members noted that wildlife (particularly large mammals) continued to be a liability more than an asset (Table 1). These views on wildlife were independent of sex, location in the group ranch and group ranch membership (Table 3). However, it was dependent on group ranch status (more positive for officials), age (more positive for younger ages), ethnicity (more positive for the Maasai), and group ranch membership (more positive for group ranch members). Main losses to wildlife included crop raiding, livestock depredation and injury / death to humans respectively.

A majority of farmers were experience crop failures (Table 1) due to wildlife damages (due to mainly increasingly deteriorating electric fence conditions). The leading crop raiding animals were African elephant (Loxodonta Africana), African buffalo (Cyncerus caffer), zebra (Equus burchelli) and gazelles (Gazella granti, Gazella thomsonii) respectively. Almost all group ranch members observed that when the electric fences (Kimana and Namelok) were established, they reduced human wildlife conflicts (Table 4), but the conflicts were on a rise after the deteroriation and increasing collapse of the electric fences. A significant majority of the members were in agreement that it was the governments' responsibility to pay compensation for losses due to wildlife to the community (Table 4).

Most group ranch members supported allowing wildlife ranging freely on their land (Table 4). This opinion on free wildlife movement in the group ranch (Table 3) was independent of location in the group ranch, but it was dependent on sex (men supported more than woman), group ranch status (ordinary members more opposed to it than officials), age (younger people more opposed than older), ethnicity (maasai pastoralists more tolerant than farmers and non-Maasai), education level (more educated members were 
Table 4. People's Responses Towards Electric Fence, Wildlife Movement and Benefits from Community Conservation

\begin{tabular}{|c|c|c|c|}
\hline Information Sought & Responses from People & $\begin{array}{c}\text { Number of Respondents }(n=127) \\
\text { (Frequencies and \%) }\end{array}$ & $\begin{array}{l}\text { Chi Square Goodness of } \\
\text { fit; df; P-Value }\end{array}$ \\
\hline \multirow{2}{*}{$\begin{array}{l}\text { Have electric fences contributed to human-wildlife } \\
\text { conflict reduction? }\end{array}$} & Yes & $125(98.4)$ & \multirow{2}{*}{$\begin{array}{c}\chi^{2}=119.126, \mathrm{df}=1 \\
\mathrm{p}<0.001\end{array}$} \\
\hline & No & $2(1.6)$ & \\
\hline \multirow{2}{*}{$\begin{array}{l}\text { Did you experience loss of livestock before fence } \\
\text { establishment? }\end{array}$} & Yes & $127(100)$ & \multirow[t]{2}{*}{ No analysis necessary } \\
\hline & No & 0 & \\
\hline \multirow{2}{*}{$\begin{array}{l}\text { Have the electric fence tampered wildlife free } \\
\text { ranging between Amboseli and Tsavo west? }\end{array}$} & No & $70(55.1)$ & \multirow{2}{*}{$\begin{array}{c}\chi^{2}=1.331, \mathrm{df}=1 \\
\mathrm{p}=0.249\end{array}$} \\
\hline & Yes & $57(44.9)$ & \\
\hline \multirow{2}{*}{$\begin{array}{l}\text { Do you support wild large mammals to move freely } \\
\text { in group ranches? }\end{array}$} & Yes & $94(74.0)$ & \multirow{2}{*}{$\begin{array}{c}\chi^{2}=29.299, \mathrm{df}=1 \\
\mathrm{p}<0.001\end{array}$} \\
\hline & No & $33(26.0)$ & \\
\hline \multirow{2}{*}{$\begin{array}{l}\text { Whether benefits from wildlife and KCWS } \\
\text { received are enough }\end{array}$} & No & $117(92.1)$ & \multirow{2}{*}{$\begin{aligned} \chi^{2}= & 90.150, \mathrm{df}=1 \\
\mathrm{p} & <0.001\end{aligned}$} \\
\hline & Yes & $10(7.9)$ & \\
\hline \multirow[t]{2}{*}{ Who should pay for damages by wildlife? } & KWS/ Government & $107(84.3)$ & \multirow{2}{*}{$\begin{array}{c}\chi^{2}=59.598, \mathrm{df}=1 \\
\mathrm{p}<0.001\end{array}$} \\
\hline & $\begin{array}{l}\text { Benefactors (e.g. local } \\
\text { tourism investors) }\end{array}$ & $20(15.7)$ & \\
\hline \multirow[t]{2}{*}{ Did you support the establishment of KCWS? } & Yes & 77 (60.6) & \multirow[t]{2}{*}{$\chi^{2}=5.740, \mathrm{df}=1, \mathrm{p}=0.017$} \\
\hline & No & $50(39.4)$ & \\
\hline \multirow{3}{*}{$\begin{array}{l}\text { Who should manage the local community Wildlife } \\
\text { Sanctuary? }\end{array}$} & Community & $103(81.1)$ & \multirow{3}{*}{$\begin{array}{c}\chi^{2}=130.457, \mathrm{df}=2 \\
\mathrm{p}<0.001\end{array}$} \\
\hline & Partnership & $13(10.2)$ & \\
\hline & Leaser & $11(8.7)$ & \\
\hline \multirow{2}{*}{$\begin{array}{l}\text { Do you think wetlands (for dry season grazing) } \\
\text { were declining? }\end{array}$} & Yes & $110(86.6)$ & \multirow{2}{*}{$\begin{array}{c}\chi^{2}=68.102, \mathrm{df}=1 \\
\mathrm{p}<0.001\end{array}$} \\
\hline & No & $17(13.4)$ & \\
\hline \multirow{3}{*}{$\begin{array}{l}\text { What are the causes for depletion and impacts on } \\
\text { wetlands? }\end{array}$} & Cultivation & $78(61.4)$ & \multirow{3}{*}{$\begin{array}{c}\chi^{2}=55.008, \mathrm{df}=2 \\
\mathrm{p}<0.001\end{array}$} \\
\hline & Overgrazing & $39(30.7)$ & \\
\hline & No idea & $10(7.9)$ & \\
\hline
\end{tabular}

mostly tolerant) and group ranch membership (members support free movements more than non - group ranch members). However, local community opinion on whether electric fences interfered wildlife movements was split with a slight majority $(55 \%)$ conceding that fences would interfere with wildlife movements (Table 4).

Almost all group ranch members lamented the lack of enough benefits from Kimana Community Wildlife Sanctuary (KCWS). Nevertheless, the majority of the members $(61 \%)$ still supported the establishment of KCWS in 1996 (Table 4). On management of KCWS, a clear majority of the members $(81 \%)$ wanted $\mathrm{KCWS}$ to be managed by members themselves rather than to be leased to a foreign tourist investor or any other party (Table 4) to safeguard their interests.

The main sources of livelihood for group ranch members were livestock keeping and cultivation (Table 3). These sources of livelihood were independent of sex and location in the group ranch, but were dependent on group ranch status (most officials with more diverse sources of income), age (young favour both farming and pastoralism), ethnicity (Maasai now favor agropastoralist while non - maasai favor mostly farmers), the level of education (more learned people had more diverse sources of livelihood) and group ranch membership (members have more diverse livelihood than non - members). However, management of land and its resources by the elected group ranch officials was criticized, as many (69\%) group ranch members felt that the performance of the elected officials was poor.

Distance to critical resources by the community varied (Table 5). Critical resources that were unavailable within two kilometers of community bomas were firewood and house roofing materials. Resources available but very scarce within that same distance were stones / sand for construction, building poles and plant fencing materials. Even though most of the resources were accessible within five kilometers, the majority such as firewood, house thatching material, medicinal plants and stone / sand building materials were found beyond five kilometers (Table 5). 
Table 5. Accessibility of Community Members to Critical Resources Useful for Local Livelihoods in Kimana Group Ranch

\begin{tabular}{|c|c|c|c|}
\hline Resource & $\begin{array}{c}\text { Frequency of Members Supply } \\
\text { within } \mathbf{0 - 2} \mathbf{~ k m}(\mathbf{n = 1 2 7}) \mathbf{( \% )}\end{array}$ & $\begin{array}{c}\text { Frequency of Members Supply } \\
\text { within 2-5 km (n=127) (\%) }\end{array}$ & $\begin{array}{c}\text { Frequency of Members Supply within } \\
\text { Greater than 5 km (n=127) } \mathbf{( \% )}\end{array}$ \\
\hline \hline Firewood & - & $23(18.1)$ & $104(81.9)$ \\
\hline Drinking water & $51(40.2)$ & $61(48.0)$ & $15(11.8)$ \\
\hline Fencing material & $12(9.4)$ & $58(45.7)$ & $57(44.9)$ \\
\hline Thatching material & - & $21(16.5)$ & $106(83.5)$ \\
\hline Building poles & $7(5.5)$ & $22(17.3)$ & $98(77.2)$ \\
\hline Medicinal plants & $15(11.8)$ & $54(42.5)$ & $58(45.7)$ \\
\hline Stones/ sand & $6(4.7)$ & $31(24.4)$ & $90(70.9)$ \\
\hline
\end{tabular}

\section{DISCUSSION}

Competition over land, water and pasture among group ranches in Amboseli area is more intense in Kimana than in other neighboring group ranches because of an active economy centered around agriculture, and heavy ecotourism investments (such as tourist lodges) [35]. The area has been a main source of horticultural produce for Mombasa and nearby urban communities for now over thirty years [20]. The construction of electric fences to reduce wildife damage of crops stimulated rapid agricultural productivity [34] in the group ranch. However, expansion of agriculture has excluded wildlife use and majority livestock access to water and pasture previously available [34]. The result has been land and resource use competition among people, livestock and wildlife, especially along rivers and swamps critical for large mammal survival during the dry season and roughts $[24,25]$.

In a recent mapping [34], the electric fences, other human structures and activities covered $22.4 \%$ and displaced wildlife from a total of $43.3 \%$ of the group ranch. This left only $56.7 \%$ of the group ranch for wildlife and only $47 \%$ for pastralism (as the current management of KCWS does not allow livestock in its $24.04 \mathrm{~km}^{2}$ area). Therefore less than half of the group ranch land is available for both wildlife and livestock, hence heightening the competition for space and resources. This is leading to increased farmer vs. herder as well as farmer vs. wildlife conflicts due to crop raiding and water diversion upstream [20]. Increase in human settlements is further likely to have a negatively impact pastoralism and wildlife [10].

The shift from pure pastoralism to agriculture or agropastoralism is not entirely new [35]. However, in Kimana, it has taken a more commercial nature rather than subsistence farming. Group ranch members noted that agricultural expansion and human development represent the most visible and significant changes in the landscape character of the area. While they blame it on depressed livelihood, droughts and educational enlightenment, there could be other reasons mostly related to better economic prospects $[20,22]$. It is likely that the impoverishment of the people makes them to desperately seek alternative sources of livelihoods to uplift their standards of living, if not only to just meet their basic needs, irrespective of the resource capacity for sustainability and associated environmental degradation. Decline and challenges against pastoralism has led a diversification of livelihoods such as agriculture [41].

Agriculture is popular with because it brings direct and significantly more income to households than pastoralism and conservation [18]. Consequently, any place with reliable water is often rapidly cleared to pave way for new agricultural fields. Riverine areas are being cleared of Acacia and other natural vegetation which are then converted into firewood or charcoal and sold in market centers [42]. The Kimana Swamp, which provided most water and dry season grazing for both wildlife and livestock $\mathrm{n}$ the area, has largely been converted into irrigation agriculture. Wildlife movements from Amboseli National Park into KCWS from the southern part have been interrupted by agriculture and boma clusters. Agriculture expansion and electric fencing has also blocked off wildlife migration corridors. Most documented is the Mt. Kitendeni wildlife corridor from Amboseli Park to Mt. Kilimanjaro which has shrunk by $70 \%$ from 1952 to 2001 mainly due to similar causes [43] as those operating in Kimana Group Ranch now.

Most of the agriculture in Amboseli area is heavily depended on irrigation [25]. Previously flowing and permanent rivers have turned into seasonal (wet season) that are dry throughout the year due to the diversion of water into agricultural fields'. The little water that manages to trickle down the rivers is heavily polluted by fertilizers and pesticides used in horticultural fields $[44,45]$ due to high alkalinity. Further, the soils of a rangeland get easily exhausted and therefore must rely on fertilizer supplements to support continuous crop production [46]. Alkalinity and heavy agriculture inputs have led to increased abandonment of agricultural fields after a short use, leading to widespread degradation that may take long to restore.

There are now incidences of conflicts between pastoralists (seeking water for their livestock) with farmers who are not allowing water to flow downstream in rivers [47]. These conflicts are likely to intensify in the future as irrigation-dependent agriculture expands and commercially driven diverse ethnic communities with different land use history and interests [48] increase in the group ranch. This has already been reported elsewhere in the ecosystem [20]. Another important previously permanent swamp fed by these rivers (such as Osoit Pus near Chyulu) have shrunk or become seasonal. This has reduced the use of pastures in the 
Chyulu Hills area in the dry season. The water crisis in the area has been worsened by the government water pipeline that carried most water from Nolturesh River to towns near Nairobi [20]. The local resentment because of this water extraction from an area starved of water has further discouraged any responsible use or initiatives aimed at proper use and management of limited water sources in the area.

Competition for land and resources has led to intense human - wildlife conflicts. People feel that the government does not take their plight seriously on providing them with monetary and other benefits from parks in addition to compensation for the costs of conservation [18, 26, 27]. As a result, retaliatory killings of wild mammals occur around $82 \%$ of Kenya's protected areas [1] in protest of losses to wildlife. Further, money generated by parks and community sanctuaries from tourism revenue mostly go to local elites [49], foreign tour investors or the government [26]. Very little money ever reaches local people despite the fact that they are the ones who are sharing land and resources with wildlife. Consequently, wildlife conservation is only likely to be supported by local communities if tangible economic and other benefits returns are realized [24, 50-54] and if they are involved in resource management $[17,55]$. Community sanctuaries as a way of involving communities is a good initial step, but there are challenges in implementation, local accountability and transparency, together with appropriate professional marketing and product standards [56, 57], especially if conservation has to be integrated in rural development [58].

Ready access to other basic natural resources by communities for survival is also getting difficult with time. The Maasai community is heavily dependent on plant resources for traditional medicinal care, for shelter, for fuel, for fencing among other uses [42]. This dependence is increasing as other land uses, particularly cultivation, lead to clearing natural vegetation. They therefore have to walk further and longer to access various plant resources for basic use. Clean drinking water is becoming also scarce because of diversion into farms from available rivers and springs [59]. Water flow in rivers is also becoming less due to hydrological and deforestation activities in the catchments area of Mt. Kilimanjaro.

Reasons for the popularity of group ranch sub-division have been sufficiently elaborated elsewhere [12, 14, 18, 20]. What is noteworthy is that this process is envisaged by the community as going to give greater independence in the management of land and utilizing it in more profitable ways. Kimana Group Ranch is now fully sub-divided. Group ranch members were given land in areas of agricultural potential and more land in open rangeland for pastoralism. The desire to practice agriculture or lease land and get money directly from those interested in cultivation has been another motivation behind group ranch subdivision [20]. There are also historical injustices in terms of annexing of Maasai lands by the government to establish protected areas and to settle landless people from other communities [60, 61]. The fear of a new spade of land losses is a very strong motive towards subdivision as Maasai believe individual ownership will secure the land than communal ownership [12].
Establishment of community - owned wildlife sanctuaries is taking off in the ecosystem [62] as a way of not only expanding wildlife range, but bringing wildlife based tourism benefits directly to the people and as another way of enlisting landowners to support wildlife dispersal [28]. Almost every group ranch in the ecosystem (except Rombo Group Ranch) has one or more ecotourism venture or a wildlife sanctuary or concession area [62]. Most conservation concerns about dispersal areas can possibly be solved if critical dispersal areas are clearly identified and established and negotiations with individual landowners (of subdivided land) for compensation or direct payment given to secure such critical areas [54]. This may be more effective than dealing with unpopular group ranch leadership, and hence provide an opportunity for a new phase of community involvement in wildlife conservation in the area.

As a new and encouraging initiative, recently, after Kimana Group Ranch subdivision, several individual land owners and organized land owners groups are in the process of merging their land to form private wildlife sanctuaries or establish tourism facilities (such as camp site or lodge) in partnership with an ecotourism investor. However, wildlife based tourism investments is a complex business that needs expertise in management, marketing and ecology. It can also be greatly manipulated by local elites for their benefits [ 49 , 59, 63]. Wildlife sanctuaries fully owned by individual (or group of organized) land owners are likely to succeed than those owned jointly in communal ownership because of accountability and transparency issues. Community-based conservation however, may or may not be the solution for empowering local communities [57]. Okello and other researchers [62] have elaborated on considerations guidelines for the establishment of communally owned wildlife sanctuaries, among other proposals [64, 65].

Many community members would like to be fenced in or have wildlife fenced in protected areas if they cannot be compensated adequately for losses. The demand for electric fences to fence humans in or wildlife out will continue to increase in the Amboseli area irrespective of their negative impacts on land use and wildlife [34]. As human competition for resources increases in the Kimana Group Ranches, there is increasing demand for complete separation between people and their livelihood from wildlife. Use of electric fences in poor rural communities such as in Kimana area without mechanisms and structures for technical and financial support, and with a successful community ownership of such initiatives is failing [34]. Fences have their own expenses and limitations in controlling human wildlife conflicts in poor rural settings. Electric fences are not only expensive to construct, but needs over US\$150 per $\mathrm{km}$ per year of maintenance, and even though, they must be accompanied by other remedies to succeed in mitigating wildlife (particularly elephant) caused damages [66].

Finally, an urgent consensus is needed on sharing of water resources between different users, and how to formulate and adopt a negotiated land use plan that will cater of all land and resource use, while conserving critical representative habitats needed by people, livestock and wildlife. This will not only help maintain wildlife movement beyond protected areas as envisaged by Western [67] and wished by Hackel [56], and also secure the environment as a 
working place where the local people live and use resources for their wellbeing.

\section{ACKNOWLEDGEMENT}

We would like to thank The School for Field Studies and its Center for Wildlife Management Studies in Kenya provided logistical support for this study. We thank the University of Nairobi for the funding and supporting third and fourth authors in the course of this study. We thank all our field interpreters and translators, Kimana Group Ranch officials and all community members for having participated in the interviews and discussions that were part of this study. We thank Miss Katie Gratsy for helping with initial editing of this paper. Lastly, but not the least, we thank anonymous reviewers for improving earlier manuscripts.

\section{REFERENCES}

[1] Okello MM, Kiringe JW. Threats to biodiversity and the implications in protected and adjacent dispersal areas of Kenya. J Sustain Tour 2004; 12(1): 55-69.

[2] MacArthur RH, Wilson. The theory of island biogeography. Princeton University Press, Princeton, New Jersey, USA, 1976.

[3] Fahrig L. Relative effects of habitat loss and fragmentation on population extinction. J Wildl Manage 1997; 61: 603-10.

[4] Burkey T. Faunal collapse in East African game reserves revisited. Biol Conserv 1994; 7(1): 107-10.

[5] Newmark WD. Insularization of Tanzanian Parks and the local extinction of large mammals. Conserv Biol 1996; 10(6): 1549-56.

[6] Soule ME, Wilcox BA, Holtby C. Benign neglect: a model of faunal collapse in game reserves of East Africa. Biol Conserv 1979; 15: 259-72.

[7] Western D, Ssemakula J. The future of Savannah ecosystems: ecological islands or faunal enclaves? African J Ecol 1981; 19: 719.

[8] Mwale S. Changing Relationships. Swara 2000; 22(4): 11-7.

[9] Johnstone R. Talking ecotourism. Swara 2000; 22(4): 5- 9.

[10] Lamprey RH, Reid RS. Expansion of human settlement in Kenya's Maasai Mara: what future for pastoralism and wildlife? J Biogeogr 2004; 31: 997-1032.

[11] Newmark WD. The role and design of wildlife corridors with examples from Tanzania. Ambio 1993; 22: 500-4.

[12] Galaty J. The land is ours: social and economic factors in the privatization, sub - division and sale of Maasai ranches. Nomad People 1992; 30: 26-40.

[13] Munei KO, Galaty JG. Maasai, law, and dispossession. Cult Surv Q 1999; 22(4): 68-76.

[14] Ntiati P. Ranches subdivision study in Loitokitok division of Kajiado district, Kenya. Land Use Change Impacts and Dynamics (LUCID), International Livestock Research Institute, Nairobi, Kenya, Working Paper 7. 2002.

[15] Munei K. Study on subdivision of group ranches in Kijiado District. Department of Agricultural Econmics, University of Nairobi, Nairobi, Kenya, 1991.

[16] Seno SK, Shaw WW. Land tenure policies, maasai traditions, and wildlife conservation in Kenya. Soc Nat Resour 2002; 15: 79-88.

[17] Wishitemi BEL, Okello MM. Application of the protected landscape model in southern Kenya. Parks 2003; 13(2): 12-21.

[18] Okello MM. Land use changes and human - wildlife conflicts in the amboseli area, Kenya. Hum Dimens Wildl 2005; 10(1): 19-28.

[19] Fratkin E. Pastoral land tenure in Kenya: Maasai, Samburu, Boran, And Rendille experiences 1950-1990. Nomad People 1994; 34: 5568.

[20] Campbell DJ, Gichohi H, Mwangi A, Chege L. Land use conflict in Kajiado District, Kenya. Land Use Policy 2000; 17: 337-48.

[21] Kituyi M. Becoming Kenyans: Socio - Economic Transformation of the Patoral Maasai. Acts Press. Nairobi, Kenya, 1990.

[22] Desta S, Coppock DL. Pastoralism under pressure: tracking system change in Southern Ethiopia. Hum Ecol 2004; 32(4): 465-75.

[23] Juma C, Ojwang JB. In: Land We Trust: Environment, Private Property and Constitutional Change. Initiatives Publishers, Nairobi, Kenya, 1996.
[24] Barrow E, Lembuya P, Ntiati P, Sumba D. Knowledge, attitudes and practices concerning community conservation in Kuku and Rombo Group Ranches around Tsavo West National Park. Community Conservation Discussion Paper No. 12. African Wildlife Foundation Discussion Papers Series. Nairobi, Kenya, 1993.

[25] Worden J, Reid R, Gichohi H. Land-Use impacts on large wildlife and livestock in the swamps of the greater Amboseli Ecosystem, Kajiado District, Kenya. The Land Use Change, Impacts and Dynamics (LUCID) Project. Working Paper Series Number 27. International Livestock Research Instititue (ILRI), Nairobi, Kenya, 2003.

[26] Sindiga I. Wildlife-based tourism in Kenya: land use conflicts and government compensation polices over protected areas. J Tour Stud 1995; 6(2): 45-55.

[27] Kenya Wildlife Service, KWS. Wildlife-Human Conflicts In Kenya. Report Of A Five-Person Review Group. KWS Official Document. Nairobi, Kenya, 1994.

[28] Western, D. Amboseli National Park: enlisting landowners to conserve migratory wildlife. Ambio 1982; 11(5): 302-8.

[29] Lichtenfeld LL. Local Participation and Conservation in Kenya: A Case Study if the Kimana Community Wildlife Sanctuary. Yale University, School for Foresty and Environmental Studies, New Haven, Connecticut, USA. The $12^{\text {th }}$ Annual Meeting of the Society of Conservation Biology. July 13-16, 1998.

[30] Okello MM, Manka SG, D'Amour DE. The Relative Importance of Large Mammal Species for Tourism in Amboseli National Park, Kenya. Tour Manage 2008; 29(4): 751-60.

[31] Katampoi K, Genga G, Mwangi M, Kipkan J, Seitah J, Van Klinken M, Mwangi SM. Kajiado District Atlas. ASAL Programme Kajiado, Kajiado, 1990.

[32] Irigia BK. Kenya Wildlife Service environmental impact assessment of the proposed Kimana Wildlife Sanctuary. Community Wildlife Service, KWS, Nairobi, Kenya, 1995.

[33] Gichohi H, Mwangi E, Gakahu C. Savanna ecosystems. In EastAfrican ecosystems and their conservation. McClanahan $\mathrm{T} R$, Young T P. Eds. Oxford University Press, New York, New York, USA. 1996; pp 273-98.

[34] Okello MM, D'amour DE. Agricultural expansion within kimana electric fences and implications for natural resource conservation around Amboseli National Park, Kenya. J Arid Environ 2008; 72: 2179-92

[35] Campbell D, Lusch D, Smucker T, Wangui E. Root Causes of Land Use Changes in the Loitoktok Area, Kajiado District, Kenya. Land Use Change Impacts and Dynamics (LUCID) Project Working Paper 19. International Livestock Research Institute. Nairobi, Kenya, 2003.

[36] Freese F. Elementary forest sampling. Agriculture Handbook 232. Forest Service, U.S. Department of Agriculture. Corvallis, Oregon, USA, 1962.

[37] Ratti, J. T. \& Garton, E.O. Research and experimental design. In Research and management techniques for wildlife and habitats. Bookhout T, Ed. The Wildlife Society, USA, 1994, pp 1-23.

[38] Zar JH. Biostatistical Analysis. $4^{\text {th }}$ ed. Prentice-Hall, Inc., Upper Saddle River, New Jersey, USA, 1999.

[39] Drijver C. Participatory Rural Appraisal (PRA): a challenge for people and protected areas. Parks 1994; 4(1): 35-40.

[40] Kumar S. Methods for community participation: a complete guide for practitioners. ITTG Publishing, London, 2002.

[41] Galaty J. Rangeland tenure and pastoralism in Africa. In African pastoral systems: an integrated approach. Fraktin E, Galvin KA, Roth EA, Eds. Boulder, Colorado, USA. 1994; pp 212-9.

[42] Kiringe JW, Okello MM. Use and availability of tree and shrub resources on maasai communal rangelands near Amboseli, Kenya. African J Range Forage Sci 2005; 22(1): 37-46.

[43] Noe C. The Dynamics of Land Use Changes and their Impacts on the Wildlife Corridor between Mt. Kilimanjaro and Amboseli National Park, Tanzania. The Land Use Change, Impacts and Dynamics (LUCID) Project. Working Paper Series Number 31. International Livestock Research Instititue (ILRI), Nairobi, Kenya, 2003.

[44] Pesticide Action Network North America. PAN Pesticides Database. 2005, http://www.pesticideinfo.org [Accessed 04/28/2006].

[45] Githaiga JM. Survey of water quality changes with land use type in the Loitoktok Area, Kajiado District, Kenya. Land Use Change 
Impacts and Dynamics (LUCID) Project Working Paper 35. International Livestock Research Institute, Nairobi, Kenya, 2003.

[46] Okello MM, Grasty K. Contraction and status of maasai lands as wildlife dispersal areas and implications for wildlife conservation in Amboseli Ecosystem, Kenya. In Harris JD, Brown PL, Eds. Wildlife: Destruction, Conservation and Biodiversit". A Wildlife Protection, Destruction and Extinction Nova Publishers Book Series. Nova Science Publishers Inc. 2009; pp. 49-96.

[47] Fratkin E, Wu TS. Maasai and Barabaig herders struggle for land rights in Kenya and Tanzania. Cult Surv Q 1997; 21(3): 55-63.

[48] Fedders A, Salvadori C. Peoples and cultures of Kenya. Transafrica Book Distributors, Nairobi, Kenya, 1979.

[49] Thompson M, Homewood K. Entrepreneurs, elites, and exclusion in maasailand: trends in wildlife conservation and pastoralist development. Hum Ecol 2002; 30(1): 107-38.

[50] McNeely J. Economic incentives for conserving biodiversity: lessons for Africa. Ambio 1993; 22(2): 144-50.

[51] Norton-Griffiths M, Southey C. The opportunity costs of biodiversity conservation in Kenya. Ecol Econ 1995; 12: 125-39.

[52] Norton-Griffiths M. Property-rights and the marginal wildebeests: An economic analysis of wildlife conservation options in Kenya. Biodivers Conserv 1996; 5(12): 1557-77.

[53] Emerton L. Economic incentives for biodiversity: How Eastern African countries are making biodiversity attractive. Innovation: Biodiversity for Secure Livelihoods in Africa 2000; 7(1): 17-20.

[54] Ferraro PJ, Kiss A. Direct payments to conserve biodiversity. Science 2002; 298: 1718-9.

[55] Beresford M, Phillips A. Protected Landscapes: A Conservation model for the $21^{\text {st }}$ century. George Wright Forum 2000; 17: 15-26.

[56] Hackel J. Community conservation and the future of Africa's wildlife. Conserv Biol 1999; 13(4): 726-34.

[57] Adams WM, Hulme D. If community conservation is the answer in Africa, what is the question? Oryx 2001; 35(3): 193-200.

[58] Alpert P. Integrated conservation and development projects. Examples from Africa. Bioscience 1996; 46(11): 845-55.
[59] Ogolla BD, Mugabe J. Land tenure systems and natural resource management. Juma C, Ojwang JB, Eds., In Land We Trust: Environment, Private property and Constitutional Change. ACTS Environmental Policy Series No. 7. Initiative Publishers. Nairobi, Kenya, 1996; pp. 121-44.

[60] Okello MM. Contraction of Wildlife Dispersal Area and Displacement by Human Activities in Kimana Group Ranch near Amboseli National Park, Kenya. Open Conserv Biol J 2009; 3: 4956.

[61] Fratkin E. Pastroralism: governance and development issues. Annu Rev Anthropol 1997; 26: 235-61.

[62] Okello MM, Seno SK, Wishitemi BL. Maasai community wildlife sanctuaries in Tsavo - Amboseli Ecosystem, Kenya: management partnerships and their conditions for success. Parks 2003; 13(1): 715 .

[63] Sibanda BMC, Omwega A. K. Some reflections on conservation, sustainable development and equitable sharing of benefits from wildlife in Africa: the case of Kenya and Zimbabwe. South African J. Wildl Res 1996; 26(4): 175-81

[64] Okello MM. An assessment of the large mammal component of the proposed wildlife sanctuary site in Maasai Kuku Group Ranch near Amboseli, Kenya. South African J Wildl Res 2005; 35(1): 63-76.

[65] Okello MM. A Survey of Tourist Expectations and Economic Potential for a Proposed Wildlife Sanctuary in a Maasai Group Ranch near Amboseli, Kenya. J Sustain Tour 2005; 13(6): 566-89.

[66] Thouless CR, Sakwa J. Shocking elephants: fences and crop raiders in Laikipia District, Kenya. Biol Conserv 1995; 72: 99-107.

[67] Western D. Conservation without parks: wildlife in the rural landscape. In: Conservation for the twenty - first century. Western D, Pearl MC, Eds. Oxford University Press, New York, New York, USA, 1989; pp. 158-65.

(c) Okello et al.; Licensee Bentham Open.

This is an open access article licensed under the terms of the Creative Commons Attribution Non-Commercial License (http://creativecommons.org/licenses/by-nc/3.0/) which permits unrestricted, non-commercial use, distribution and reproduction in any medium, provided the work is properly cited. 